\title{
“Activatable”蛍光プローブの開発に基づく高感度術中がん部位検出の実現
}

\author{
浦 野泰照 $a, b$
}

\section{Highly Sensitive and Intraoperative Detection of Tiny Tumors with Novel "Activatable" Fluorescence Probes}

\author{
Yasuteru Urano ${ }^{a, b}$ \\ ${ }^{a}$ Graduate School of Medicine, The University of Tokyo; 7-3-1 Hongo, Bunkyo-ku, Tokyo \\ 113-0033, Japan: and ${ }^{b}$ Basic Research Program, Japan Science and Technology \\ Agency; K’s Goban-cho, 7 Goban-cho, Chiyoda-ku, Tokyo 102-0076, Japan.
}

(Received October 11, 2011)

\begin{abstract}
Several versatile and rational design strategies for novel fluorescence probes including those based on photoinduced electron transfer have been successfully established. Indeed, based on these design strategies, various novel fluorescence probes were successfully developed including those for reactive oxygen species and reporter enzymes. Furthermore, we have succeeded to visualize tiny tumors in living mice by using cancer-specific antibodies tagged with acidic-pH activatable fluorescence probes. Here, I will describe the details of probe design as well as some imaging results with living cells and animals by applying our novel fluorescence probes.
\end{abstract}

Key words — fluorescence probe; photoinduced electron transfer; reactive oxygen species; reporter enzyme; cancer imaging; $\mathrm{pH}$

\section{1. はじめに}

「生きている状態の生物試料」における種々の生 理活性物質の動態を，リアルタイムかつ高感度に観 測することは，近年の生物・医学領域研究になくて はならない実験技法となっている，中でも現在，観 測対象分子を高感度に可視化する蛍光プローブを用 いて，蛍光顕微鏡下で生細胞応答を観測する技法が 広く汎用されている。

これまでに開発されてきた蛍光プローブは, GFP などの蛍光タンパク質をベースとするものと有機合 成小分子をべースとするものに大別される，蛍光夕 ンパク質をベースとするプローブは，遺伝子導入に よって細胞に発現させるだけで簡便にイメージング が可能であるという特長を持ち，キナーゼ活性から カルシウムイオンの動態など，様々なイベントを可 視化するプローブが開発されてきた。これらのプ

$a$ 東京大学大学院医学系研究科（T113-0033 東京都文 京区本郷 7-3-1), ${ }^{b}$ 科学技術振興機構戦略的創造研究 推進事業（１１02-0076 東京都千代田区五番町 7 K's 五 番町)

e-mail: uranokun@m.u-tokyo.ac.jp

本総説は, 日本薬学会第 131 年会シンポジウム OS02

で発表したものを中心に記述したものである.
ローブの作動原理は，主に 2 つ蛍光タンパク質間 のエネルギー移動（FRET: Förster Resonance Energy Transfer) であり，蛍光波長の変化を検出するこ とで検出対象分子の存在の可視化を実現している. これらのプローブは遺伝子でコードされているた め, 構成アミノ酸の point mutation によって網羅 的に変異体を作成し，最もよい応答を示すものを探 し出すという開発手法が可能であることも大きな利 点である. 一方で trial and error 式の開発しかでき ないため，検出対象分子のレパートリーはそれほど 広くない点が問題であり，その他，細胞内のプロー ブ発現量を制御することが難しい点, 蛍光タンパク 質中の蛍光団の生成に時間がかかる点，また蛍光ス ペクトルの幅が広く多色検出が困難である点などが 問題点としてょく挙げられている.

一方で有機小分子をべースとするプローブは，細 胞外液に添加するだけですべての細胞に，速やかに かつ濃度を制御して導入可能であるなどの特長を有 するため, 多種多様なプローブの開発が強く望まれ ている，本プローブ群の検出原理としては，FRET よりもむしろ蛍光消光 (quenching) がよく用いら れている，すなわち，それ自身はなんらかの消光過 
(a)

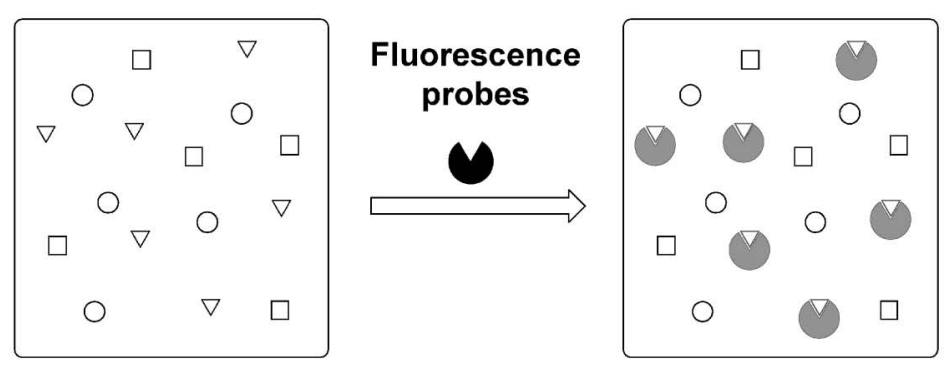

- Fluorescence probes are the photo-functional molecules whose fluorescence properties are dramatically changed upon reaction or binding with target molecules. - Fluorescence probes can visualize the target molecules in living cells. ( $S$ pecific reaction with $\nabla$ molecule causes marked fluorescence increase .)

(b)

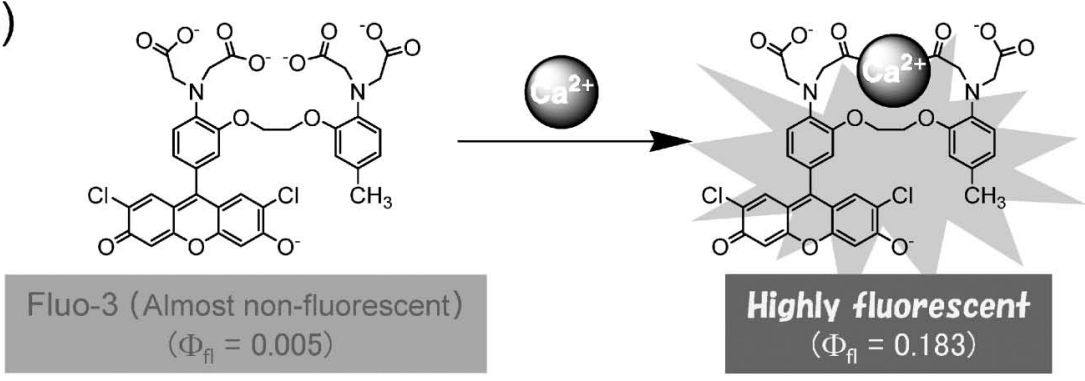

Fig. 1. (a) Functions of Fluorescence Probes and (b) A Representative $\mathrm{Ca}^{2+}$ Sensitive Fluorescence Probe, Fluo-3

程の存在により無蛍光であるが，これが観測対象分 子と反応，結合することで強い蛍光を発するように なる蛍光プローブ分子が数多く開発されてきた. Figure 1(a)に，このような合成小分子蛍光プロー ブを用いて，「生きている」細胞を「生きたまま」 観測する手法の原理を簡潔にまとめた。観測対象と する生理活性分子（ $\nabla ）$ の検出を考えるとき，ほと んごの生理活性物質は無色であるため，光学顕微鏡 でただ観察してもその動きを知ることはできないが, $\nabla$ と反応・結合することで初めて蛍光を発する合成 小分子蛍光プローブを細胞内に存在させることで, $\nabla$ の動きを蛍光の変化として, 高感度かつリアルタ イムに追うことが可能となる.

例えば， $\mathrm{Ca}^{2+}$ イオンが細胞内の情報伝達を司る 代表的なセカンドメッセンジャーとして働いている ことは，既に疑いのない事実であるが，これは $\mathrm{Ca}^{2+}$ イオンを選択的に蛍光検出可能な蛍光プロー ブの開発によるところが極めて大きい。代表的な $\mathrm{Ca}^{2+}$ イオン検出蛍光プローブである fluo-3 の構造 と $\mathrm{Ca}^{2+}$ イオン検出の原理を Fig. 1 (b) に示した.

Fluo-3 はフルオレセイン骨格と $\mathrm{Ca}^{2+}$ イオンキレー ターである BAPTA 部位とが融合した構造である が， $\mathrm{Ca}^{2+}$ フリーの状態ではほぼ無蛍光であり，こ
れが $\mathrm{Ca}^{2+}$ イオンと結合することでその蛍光強度が 36-40 倍に上昇するため, $\mathrm{Ca}^{2+}$ イオン検出蛍光プ ローブとして機能する.1)

2. 分子内光誘起電子移動に基づく蛍光プローブ の論理的精密設計法の確立

上述のように生細胞観測に極めて重要な役割を果 たす蛍光プローブであるが，これまでに開発されて きた有機小分子蛍光プローブのほとんどは trial and error 方式で開発されてきており，望みの機能を実 現する蛍光プローブを狙って開発することは極めて 困難であった。この理由として，現代の最新の量子 化学計算を駆使しても，新たな有機化合物の蛍光特 性，中でもその明るさ（蛍光量子収率）を正確に予 測することはほぼ不可能であり，それら新規物質を 実際に合成し，蛍光特性を実測してみるまで，光る か光らないかはわからないことが挙げられる，よつ てこれまで，元々は無蛍光性であり， $\nabla$ と反応・結 合することで初めて蛍光を発する蛍光プローブを開 発するには，試行錯誤に基づくことが一番の近道で あったが，この方法では新たな検出対象分子を可視 化する蛍光プローブを開発できる保証は全くなく, 実際これまでに開発されてきた蛍光プローブのター ゲットは，各種典型金属イオンなど非常に限られた 
(a)

Photoinduced electron transfer (PeT)-based quenching of fluorescence

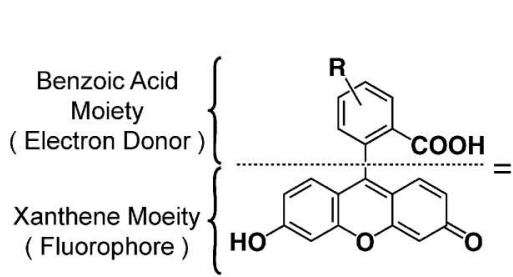

(c)

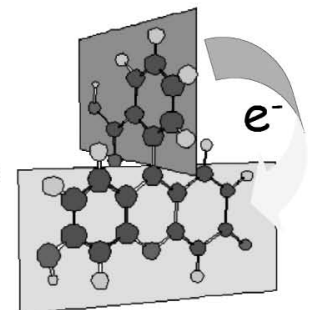

Rational Design Strategy of Fluorescence Probes \#1

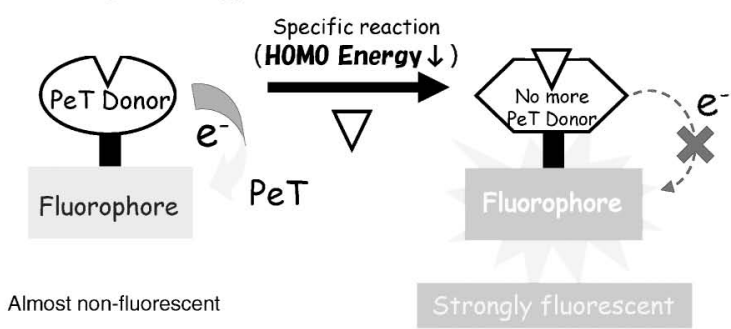

(b)

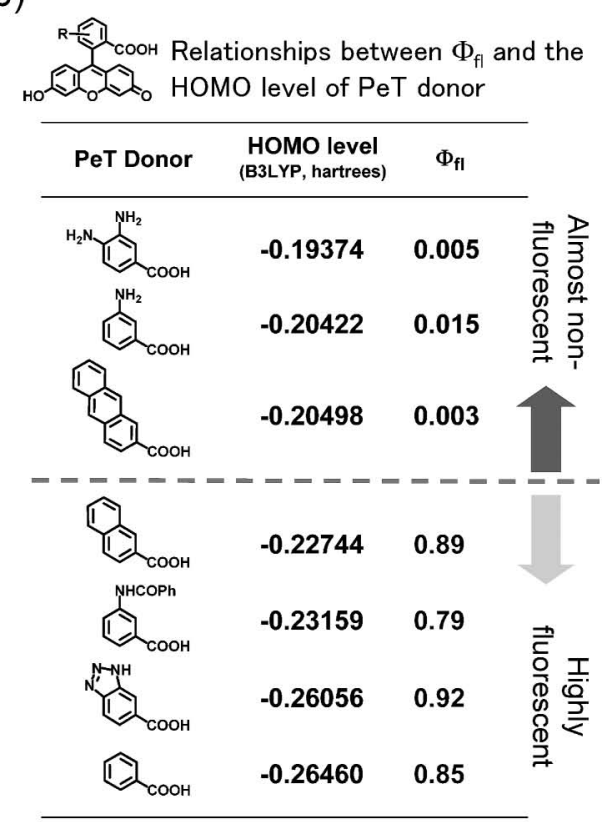

Fig. 2. Rational Design Strategy for Novel Fluorescence Probes Based on Photoinduced Electron Transfer

(a) Many visible light-excitable fluorescent molecules can be conceptually divided into two moieties, a fluorophore and an electron donor moiety. (b) Relationships between the quantum yield of fluorescence and the HOMO energy level of benzoic acid moiety of various fluorescein derivatives. (c) Novel probes could be rationally designed by using specific chemical reactions to target analytes which meet the criteria that the initial substrate has high HOMO energy and the product has lowered one.

ものであった.

そこで筆者らはこのような状況を打破し, 目的の 機能を有する蛍光プローブを論理的に精密に設計す ることを目標とした研究を行ってきた結果，光誘起 電子移動 (Photoinduced Electron Transfer; PeT) を設計原理とする蛍光プローブの論理的なデザイン 法を確立することに成功した，すなわち，例えば代 表的な蛍光分子であるフルオレセインは，分子をべ ンゼン環部位と蛍光団であるキサンテン環部位の 2 部位に分けて考えることが可能であり，分子内 PeT によりその蛍光特性を精密に制御可能である ことを見い出した [Fig. 2(a)]. 具体的には，ベン ゼン環部位の HOMO エネルギーレベルがある值よ りも高いフルオレセイン誘導体はすべてほぼ無蛍光 であり，これが低い誘導体はすべてフルオレセイン と同等の強い蛍光を発することが明らかとなった [Fig. 2(b) ]. 2,3) なぜ一般に予測不可能であった蛍 光特性を，われわれの手法を用いた分子設計では予 測可能となつたかを簡単に述べるならば，われわれ の手法では蛍光団であるキサンテン環には全く修飾 を加えておらず，蛍光団とは $\pi$ 電子共役していな いベンゼン環部位に修飾を加えているため，蛍光団
自身の基本的な特性は損なわれていないことが挙げ られる，実際，この手法に基づく分子設計では，そ の吸収・蛍光スペクトルはほとんど変化せず，量子 収率のみが変化するなど，蛍光団自身の基本的な特 性は保たれていることが明らかとなっている.

以上の知見を発展させることで筆者らは，Fig. 2 (c)に示した蛍光プローブの論理的設計法の確立に 成功した。すなわち，ある観測対象分子に対する蛍 光プローブの開発を考える際，その観測対象分子と 特異的に結合・反応し，かつその反応前後で基質の HOMO エネルギーレベルが大きく低下する化学反 応 (分光学的な変化は一切必要ない) さえ知ってい れば，これを活用して反応前は PeT によりほぼ無 蛍光であり，反応後に PeT が起こらなくなること で強い蛍光を発するプローブを論理的に開発するこ とが可能となった。

3. 各種活性酸素種 (ROS), 及び関連酵素活性 の選択的検出を可能とする蛍光プローブの論理的開 発

活性酸素種（ROS）は，炎症，がんなど多くの 疾患に係わるとされ，また近年では細胞内情報伝達 物質としての役割も持つとの指摘もあり，ますます 
注目を集めている。一口にROS と言っても，スー パーオキシド, 過酸化水素, ハイドロキシルラジカ ル，一重項酸素など多くの種が存在し，これらはそ れぞれ特徵的な化学反応性を持つことから，生体内 においても異なる役割を持つ可能性も高い，ROS 検出用蛍光プローブは，筆者らの研究以前にもいく つか開発され，中でもジクロロフルオレセインの 2 電子還元体である DCFH (Dichlorodihydrofluorescein）が広く用いられてきた。しかしながら DCFH には ROS 間の特異性は全くなく，また励起光を当 てるだけで ROS の有無にかかわらず大きく蛍光が 増大してしまう欠点を持っており，生物学的に意味 あるデー夕を得ることは困難であった．

そこで筆者らは，上述の蛍光プローブデザイン法 を活用し，ある特定の活性酸素種のみを検出可能な 蛍光プローブの精密設計を試みた結果，多数の新規 蛍光プローブの開発に成功した. ${ }^{4-7)}$ 例えば一重項 酸素 [Fig. 3(a)]，OH ラジカルなど強い酸化活性 を持つ ROS [Fig. 3(b)]，パーオキシナイトライト

[Fig. 3 (c) ] を高選択的かつ高感度に検出可能な蛍
光プローブは，アントラセンからのエンドパーオキ サイド生成反応, ${ }^{3,4)}$ ジフェニルエーテルの酸化的開 裂, 5) フェノールのニトロ化反応6) をそれぞれ鍵反 応として，論理的に開発することに成功した。

さらに，好中球に含まれるミエロパーオキシダー ゼによって産生される ROS であり，高い活性を有 する hROS の一種である次亜塩素酸を特異的に検 出可能な蛍光プローブ HySOx の開発にも成功し た. ${ }^{7)}$ そのプローブ設計原理は，これまで紹介して きた PeT とは異なり，ローダミン骨格の分子内閉 環・開環平衡の制御に基づくものであり，HySOx プローブ自身は色も蛍光も持たない化合物である が，これが次亜塩素酸イオンと反応すると通常の ローダミン蛍光を発する生成物へと変化する [Fig， $3(\mathrm{~d})$ ]。本プローブは抗光裉色性のローダミンをそ の母核とするものであるため，同一視野の連続観察 時におけるプローブの裉色が全くみられないなど, 極めて生細胞イメージングに適した性質を持つ。実 際，ブタ好中球によるザイモザン貪食時に生成する 次亜塩素酸のリアルタイム連続観測を試みたとこ (a)
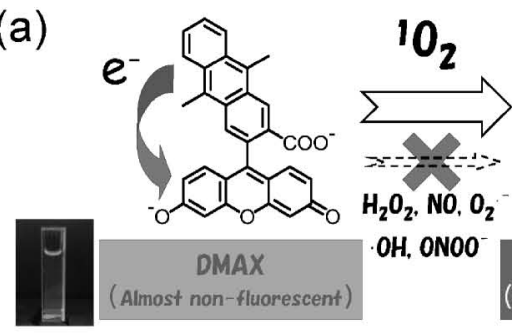

OH, ONOO

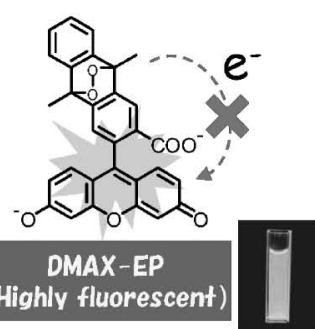

(c)

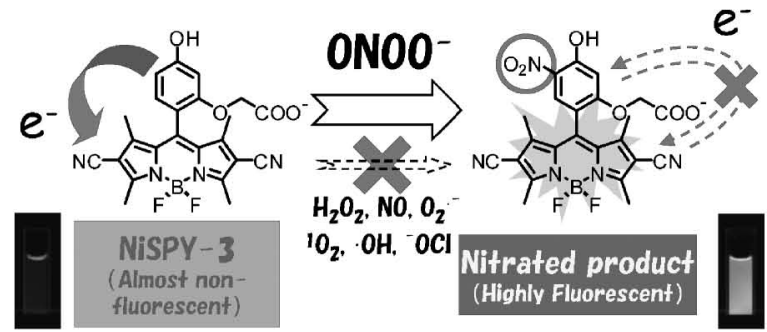

(b)

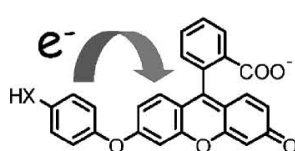

$\operatorname{HPF}(X=0), \operatorname{APF}(X=N H)$ (Almost non-fluorescent)

\begin{tabular}{crrr}
\multicolumn{4}{c}{ Reactivity for various ROS } \\
\hline $\mathrm{ROS}$ & $\mathrm{HPF}$ & \multicolumn{1}{c}{ APF } & DCFH \\
\hline${ }^{\circ} \mathrm{OH}$ & 730 & 1200 & 7400 \\
$\mathrm{ONOO}-$ & 120 & 560 & 6600 \\
$-\mathrm{OCI}$ & 6 & 3600 & 86 \\
$\mathrm{O}_{2}^{-}$ & 8 & 6 & 67 \\
${ }^{1} \mathrm{O}_{2}$ & 5 & 9 & 26 \\
$\mathrm{H}_{2} \mathrm{O}_{2}$ & 2 & $<1$ & 190 \\
$\mathrm{ROO}^{\circ}$ & 17 & 2 & 710 \\
$\mathrm{NO}$ & 6 & $<1$ & 150 \\
Autoxidation & $<1$ & $<1$ & 2000
\end{tabular}

Highly ROS

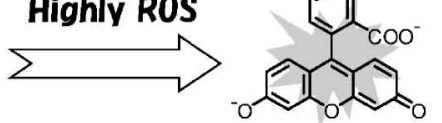

Fluorescein (Highly fluorescent)

$<$ HPF, APF>

Only hROS (ex, OH radical) can be detected No autoxidation

$\rightarrow$ Consecutive imaging can be achieved

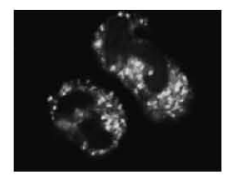

Imaging of hROS production by loading APF in porcine neutrophils upon stimulation with PMA (d)

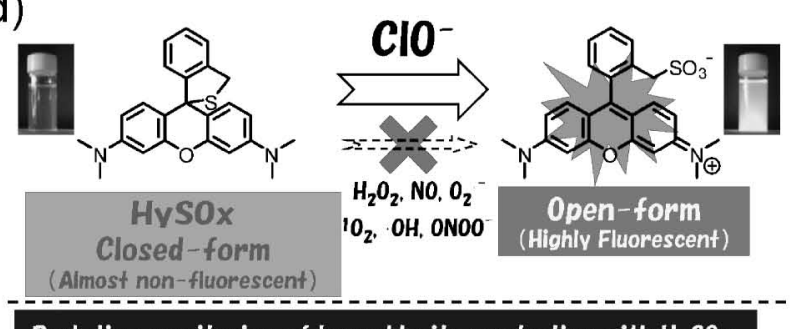

Real-time monitoring of hypochlorite production with $\mathrm{HySOx}$

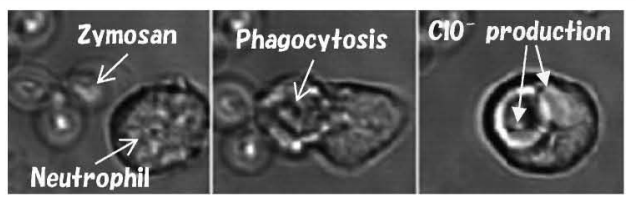

Phagocytosis

Fig. 3. Novel Fluorescence Probes for Various Reactive Oxygen Species Which Can Distinguish One Specific ROS

(a) Fluorescence probes for singlet oxygen, DPAXs and DMAXs. (b) HPF and APF for highly reactive oxygen species (hROS). (c) NiSPYs for nitrative stress. (d) A novel hypochlorite specific fluorescence probes, HySOx. 
ろ，ザイモザンを食食して生成したファゴソーム内 のみに，貪食のタイミングと極めてよく相関して， 強いローダミン蛍光が生成することが観測された。 本結果は，好中球の活性化による次亜塩素酸生成を リアルタイムで可視化した初めての例であり，白血 球の生理作用解析や，医薬品開発に大きな力を発揮 するものと期待している。

4. TokyoGreen 骨格の創製に基づく, 各種加水 分解酵素 · 反応可視化蛍光プローブの開発

さらに筆者らは，フルオレセインの骨格構造を $\mathrm{PeT}$ の観点から見直すことで，新たな蛍光プロー ブデザイン法につながる誘導体群の創製に成功し
た。すなわち上記の PeT の考え方によれば，カル ボキシ基は他の官能基に変換することが可能なはず であると考え，メチル基，メトキシ基など他の官能 基に置換した誘導体の開発に成功した [Fig. 4(a)]. 驚いたことにこれらの単純なフルオレセイン誘導体 は新規化合物であり，また以下に詳述するようにこ れらは極めて有用な蛍光プローブ母核となるもので あつたため，これらの新規蛍光骨格を TokyoGreen （以下 TGと略す）と命名した。 ${ }^{8}$ 次にこれら TGs の蛍光特性を精査した結果, ベンゼン環 HOMOエ ネルギーレベルの上昇により蛍光量子収率が減少す るという PeT の原理に一致した結果が得られたば (a)

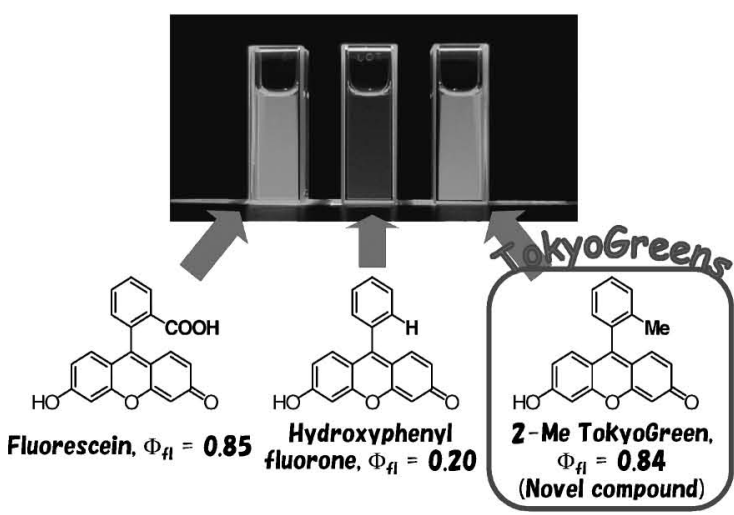

(c)
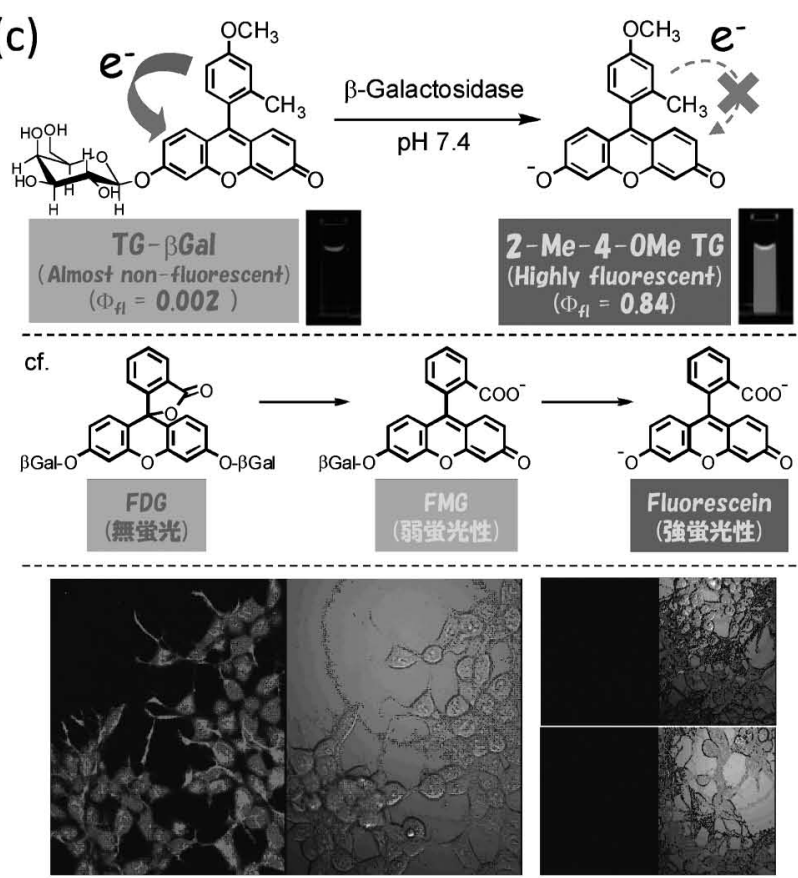

TG- $\beta$ Gal with GP293 / +lacZ (b)
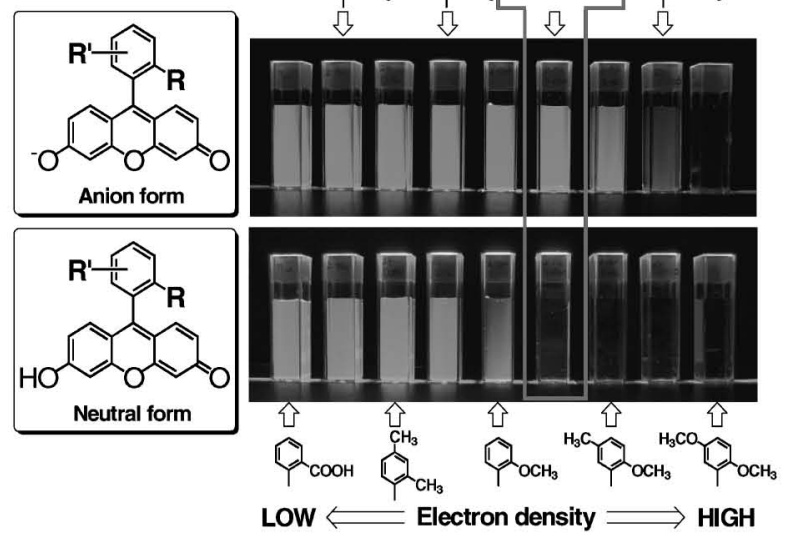

(d)
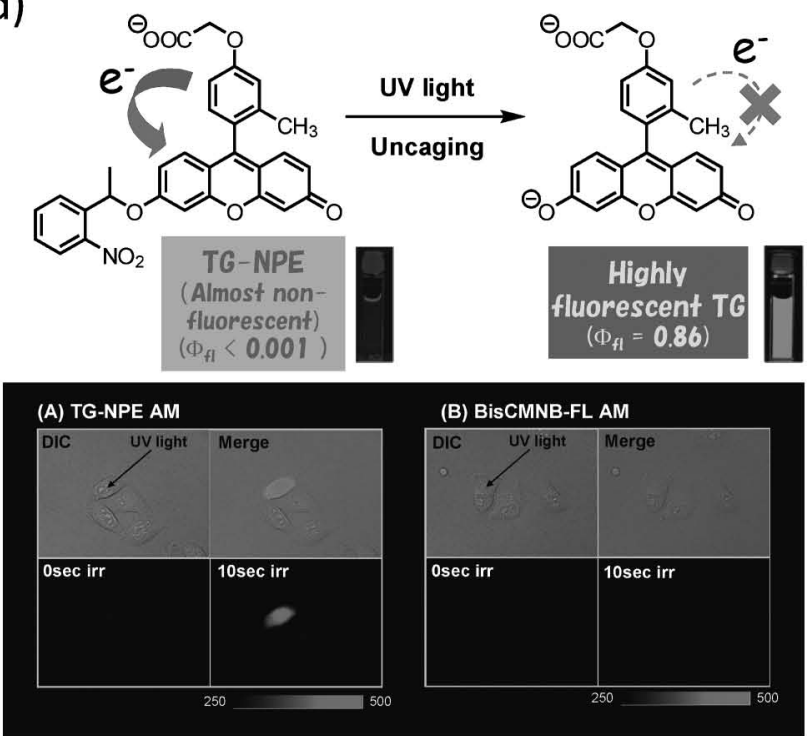

Fig. 4. Development of Novel Fluorescence Probes for Hydrolases Based on a Novel Fluorescent Scaffold TokyoGreens

(a) Development of novel fluorescent scaffold, TokyoGreens. (b) PeT-based control of fluorescence properties of TokyoGreens. (c) Development of a novel, sensitive and selective fluorescence probe, TG- $\beta$ Gal, for detecting $\beta$-galactosidase activity in living cells based on TokyoGreen scaffold. (d) Novel caged fluorophore, caged TGs, based on TokyoGreen scaffold. 
かりでなく, 蛍光 $\mathrm{On} / \mathrm{Off}$ の境界はキサンテン環部 位の水酸基がアニオン型である場合と，分子型であ る場合で大きく異なることも明らかとなった［Fig， 4(b) ]. 本知見はプローブ設計の観点から非常に有 用である。.すなわち，Fig. 4(b)の枠で囲った $m$-メ トキシトルエンをベンゼン環部位として持つ TG は，キサンテン部位がアニオン型の時は強蛍光性で ある一方，分子型になるとほぼ無蛍光であるという 特異な性質を有するキサンテン系色素と言え，極め て有用な蛍光プローブ母核となり得ることを示して いる，以下，本特性を活用して開発に成功した各種 加水分解酵素・反応可視化蛍光プローブを紹介する.

まず， $\beta$-ガラクトシダーゼ活性検出蛍光プローブ TG- $\beta$ Gal [Fig. 4 (c) ] を紹介する. TG- $\beta$ Gal は, $m$ メトキシトルエンをそのベンゼン環部位とする TG 類であり，このプローブ自身のキサンテン環部位の 水酸基は，ガラクトースと結合しているエーテル構 造となっており，よって pH 7.4 の水溶液中でも分 子型をとる結果, ほぼ無蛍光性である。これが $\beta$ ガラクトシダーゼにより特異的に加水分解されるこ とで，キサンテン環部位の水酸基はフリーとなる が，その $\mathrm{p} K_{\mathrm{a}}$ が約 6.2 であるため脱プロトン化して アニオン型となるため，生成物である 2-OMe-4-Me TG は強い蛍光を発する.すなわち本プローブは $\beta$ ガラクトシダーゼ活性検出蛍光プローブとして機能 する．実際，本反応前後での蛍光増大率は約 800 倍 にも達し，極めて鋭敏に $\beta$-ガラクトシダーゼ活性 検出が可能である.

$\beta$-ガラクトシダーゼはレポーター酵素として最も 汎用されているが，これまでの検出法は X-Gal 染 色などの吸光法を原理とするものがほとんどであ り，原理的に高感度であるはずの蛍光法が用いられ ることは非常に少なかった，今回開発に成功した TG- $\beta$ Gal は分子内に糖部位を 1 つしか持たず，こ れが加水分解される 1 段階の反応で, 従来から知ら れている蛍光プローブ [Fluorescein-di- $\beta$-galactoside; FDG, Fig. 4 (c)］の 2 段階分に相当する最大の 蛍光強度変化を生じるように設計されているため, 非常に感度よく $\beta$-ガラクトシダーゼ活性を検出す ることが可能となった．本プローブは生細胞系への 適用が可能であり，実際 Fig. 4 (c) に示したよう に，生細胞系における $\beta$-ガラクトシダーゼの高感 度検出に世界で初めて成功した。 8 ,9)
上述の設計法で用いるアルキル基部位は，もちろ んガラクトースに限られるものではない.これを光 解除性保護基であるニトロベンジル基とすれば，い わゆる caged 蛍光色素が誕生する。実際本設計法に 基づいて開発された TG-NPE は，それ自身は分子 内 PeT の結果ほぼ無蛍光であり，ここに $350 \mathrm{~nm}$ の 解除光を照射することで大きな蛍光増大を示す Caged 蛍光色素として機能する。TG-NPE は上述 の $\mathrm{TG}-\beta \mathrm{Gal}$ と同様， 1 段階の光解除性保護基の脱 離により最大の蛍光強度変化を生じるため, 従来色 素に比べ極めて短時間の解除光照射で単一細胞の蛍 光染色が可能であることも示された $[$ Fig. $4(\mathrm{~d})] .{ }^{10)}$

5. 蛍光イメージングプローブの精密設計に基づ く術中がん部位イメージング

臨床的な観点からがんは, 発見時の進行度により 患者の予後が大きく左右されることが一般的に知ら れており，実際胃がん，肺がん，結腸がん，乳がん などのがんにおいて，がんの早期発見の重要性が示 されている。従来がん診断には，PET, SPECT, MRI，及び US 技法などが用いられてきたが，これ らの技法で得られる画像は簡潔に言えばプローブの 集積度の画像である。すなわちがん集積性の高いプ ローブが，がんに集積する性質を利用して，がんの 画像化を実現するものである。しかし全プローブ分 子ががんのみに集積するわけではなく，代謝，排泄 に係わる臓器である肝臓や腎臓への集積や, 非特異 的に正常部位へと吸着，分布するプローブも多い. よって全身スキャン時にはこれが大きなバックグラ ウンドシグナルとして画像化されてしまい，結果と して小さながん部位を見逃してしまう可能性がかな り高い [Fig. 5(a)]。また例えば FDG-PET は，が ん細胞が異常に高い代謝活性を持ち，活動のエネル ギーである糖を多く取り込むことを利用したプロー ブであるため，同様に糖を大量に取り込む臓器であ る脳や細胞活動性の高い炎症部位も強いシグナルを 発するなど，がん特異性の問題も依然として残って いる.

上述の臨床画像取得技法と比較して光を検出原理 とする技法は, 光の組織透過性の問題から第一選択 の技法としては敬遠されてきた。しかしながら筆者 は，蛍光を原理とする分子イメージングに基づく画 像取得技法は，従来の技法では実現不可能ながん部 位と正常部位の質的な差異を見分けて，これを画像 
a
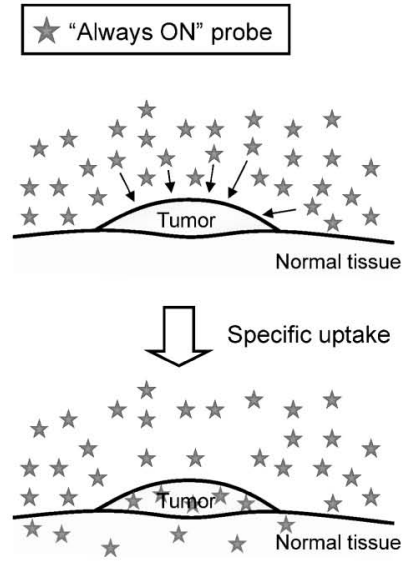

$\llbracket \begin{aligned} & \text { Washout of } \\ & \text { unbound probes }\end{aligned}$

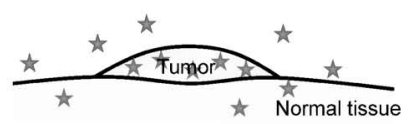

Low Tumor-to-Normal Ratio(T/N) b
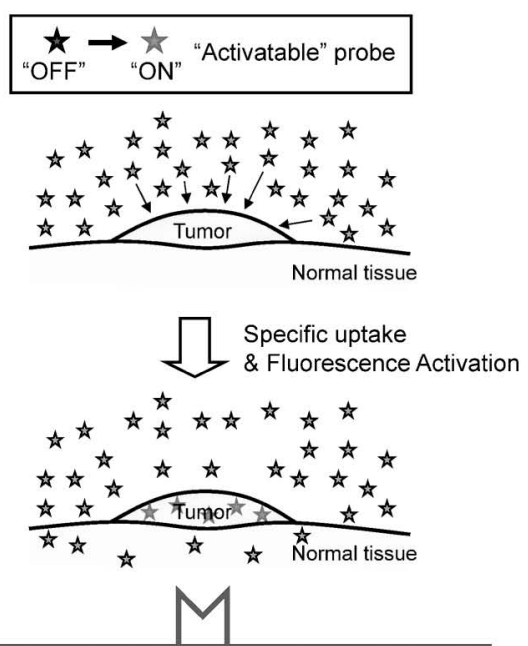

\# Probes do not fluoresce until taken up to tumor cells

\# No need to wait complete washout of probes

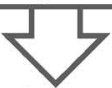

High T/N imaging can be achieved

Fig. 5. Comparison between "Always on" and Activatable Probes

(a) Existing strategies for tumor imaging with MRI, PET or non-activatable "always on" fluorescence detection. (b) Novel strategy for selective tumor imaging with activatable fluorescence probes.

化することが可能であり，高感度かつ高選択的なが んイメージングが可能となるのではと考えた［Fig. $5(\mathrm{~b})$ ］。もちろんこのようながん部位特異的な蛍光 イメージングを実現するためには，がん部位を見分 けてその蛍光特性が大きく変化する蛍光プローブの 精密設計・開発が必須となる.

一般に動物個体における in vivo がんイメージン グを考える場合，有機小分子である蛍光プローブ単 体の体内動態を精密に制御し，高いがん選択性を付 与することはほぼ不可能である。そこで筆者らは， 有機小分子プローブ単体ではなく，がん選択的に取 り込まれる抗体とこれががん細胞に取り込まれたこ とを検知する機能を持つ有機小分子プローブと組み 合わせる戦略で，高選択的in vivo がんイメージン グの実現を図った. ${ }^{11)}$ 以下，その概略を紹介する.

がん細胞に選択的に取り込まれる抗体は，現在で は抗体医薬として治療に用いられているなど，既に 数多く開発されている. これら抗体の細胞への取り 込みは，細胞表面抗原への結合をトリガーとするエ ンドサイトーシス経路で起こり，抗体は最終的に細 胞内オルガネラの 1 つであるリソソームへと運搬さ れる，すなわち，細胞内リソソームの特徵的な環境 を認識して初めて蛍光性となる蛍光プローブを開発
し，これをがん特異的抗体に結合させたプローブ複 合体を作成すれば，高選択的 in vivoがんイメージ ングを実現できるものと考えた [Fig. 6(a)]。具体 的には，リソソーム内は通常の細胞内・外の環境と 異なり弱酸性であることに着目し，中性条件下では 蛍光を持たず，弱酸性環境を検知して初めて光る蛍 光プローブの開発を行った。すなわち，アニリン部 位を酸性環境認識部位, BODIPYを蛍光団とし, アニリン部位がプロトネーションされていないとき は分子内 PeT により消光し, 酸性環境下でプロト ン化されると高蛍光性へと変化するプローブを設 計, 開発した。 さらにアニリン部位として各種アル キル置換基をアミノ基上に導入することで， $\mathrm{p} K_{\mathrm{a}}$ （蛍光・無蛍光の境目となる $\mathrm{pH）}$ の異なる一連の 弱酸性環境検出蛍光プローブ群の開発にも成功した [Fig. 6(b)]。そこでこれらの小分子蛍光プローブ を，代表的ながん特異的抗体である Herceptinへと 共有結合させ，がんイメージングプローブ複合体を 作成した。

次に開発したプローブ複合体を, Herceptin を取 り込むことが知られている HER2（上皮成長因子受 容体の 1 つ. 乳がんなどで京進していることが知ら れている）を発現している培養細胞系へと適用し 
(a)

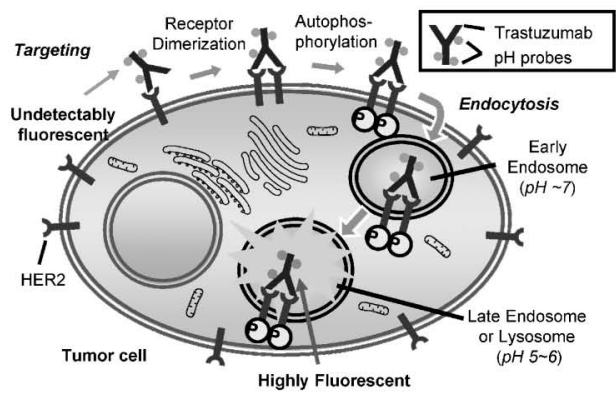

(b)

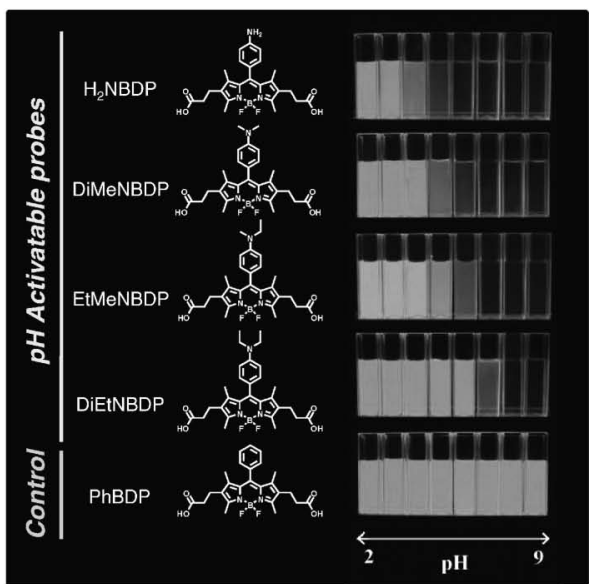

(c)

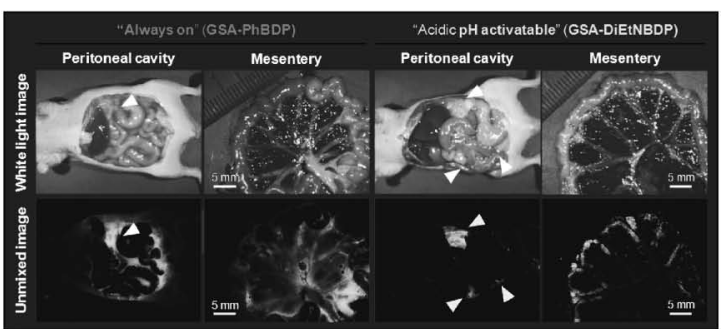

(d)

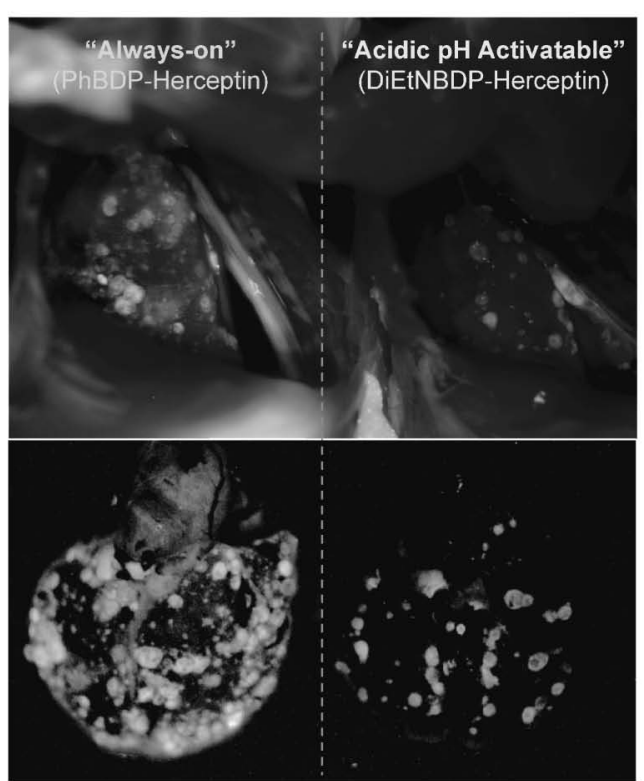

Fig. 6. Highly Selective In Vivo Fluorescence Imaging of Tiny Tumors Based on the Combination of Acidic pH-Activatable Fluorescence Probes and Cancer-specific Antibodies

(a) A novel strategy of highly selective tumor imaging with an activatable fluorescence probe-antibody conjugate. (b) pH profiles of fluorescence of H2NBDP, DiMeNBDP, EtMeNBDP and DiEtNBDP as acidic pH-sensitive fluorescence probes, and PhBDP as a control "always on" probe. The $\mathrm{pH}$ ranges from $\mathrm{pH} 2$ (left) to $\mathrm{pH} 9$ (right) in one $\mathrm{pH}$ unit increments. (c) In vivo spectral fluorescence imaging of tiny tumor nodules in the peritoneal cavity of cancer bearing mice by intraperitoneal injection of our acidic $\mathrm{pH}$ activatable fluorescence probe-antibody conjugate. (d) In vivo fluorescence tumor imaging of lung metastatic cancer model mice. Composite overlapped white light and fluorescence images of the lung (upper) and ex vivo fluorescence images of lung and heart (lower) one day after injection of always on (left) and activatable (right) imaging probes.

た．まずコントロールとして，pH に関係なく常に 強い蛍光を発する蛍光団を結合させた抗体（以下 “Always on”と表記）を細胞外に加えると，加え た直後から細胞膜上に強い蛍光が観察された。これ は Herceptin が HER2 受容体に結合していること を示している，2 時間ほどたつと，細胞内にもエン ドソーム，ライソソームに由来するドット状の明る い蛍光が観測された。本結果は，Always on プロー ブでは，がん細胞に取り込まれずに残る薬剤による バックグラウンド蛍光が極めて強いことを示すもの であり，このような単純な蛍光団一抗体の複合体で はがん部位選択的な検出は不可能であることを示す ものである. 一方, 弱酸性環境下で初めて蛍光を発 するプローブを結合させた抗体（以下 “pH-Activatable”と表記）を適用した系では，プローブ添
加直後は全く蛍光が観察されなかった. 本系でも, Herceptin と HER2 は Always on プローブの場合と 同じく強く結合しているはずであるが，プローブは pH 7.4 の細胞外に存在するため, 細胞膜上には蛍 光が観測されなかったと考えられる. その後プロー ブはエンドサイトーシスによって徐々に細胞内へと 取り込まれ，リソソーム内へと運搬され，2 時間ほ どすると細胞内にのみ明るいドット状の蛍光が観察 され始めた。これは 24 時間以上持続し, 最終的に はかなり明るい蛍光を発するようになった。 以上の 結果は, がん細胞に取り込まれることで初めて蛍光 を発するという，当初期待した通りの機能を有する ことを端的に示すものである [Fig. 6(c)].

そこで次に HER2 陽性がん細胞を肺に転移させ たがんモデルマウスに, 静脈内注射によりプローブ 
を投与し， 1 日後に開腹して肺の蛍光スペクトルイ メージングを行った．その結果，Always on プロー ブを投与したマウスでは，がん部位だけでなく，筋 肉組織や血中など，体内の至るところが蛍光を発し ており，微小がんのイメージングは不可能であった のに対して，弱酸性環境下で初めて光る $\mathrm{pH}-\mathrm{Ac}-$ tivatable 蛍光プローブを結合させた抗体を投与した マウスでは，がん部位のみが高選択的に蛍光を発し ており，バックグラウンド蛍光は極めて低いレベル に抑えることができることが明らかとなった［Fig， $6(\mathrm{~d})$ ]。次に心臓と肺を体外に取り出して ex vivo イメージングを行ったところ, Always on プローブ を投与したマウスではがん部位のみでなく，肺の表 面や心臓からも蛍光が観測されたのに対して, 弱酸 性環境検出 $\mathrm{pH}$-Activatable プローブを投与したマ ウスでは，がん部位のみが強い蛍光を発しており，

$1 \mathrm{~mm}$ 以下のごく微小ながんであっても，これを高 感度・高選択的に蛍光イメージング可能であること が明らかとなった $[$ Fig. 6(d)]。ささらに腹腔播種が んモデルマウスへと本設計指針と同様のプローブを 適用し，生きているマウス中にできている微小がん を，蛍光内視鏡を使うことで可視化することにも成 功し，本手法が実際のがん診断，手術に直結する技 術であることも確かめられた。具体的な動画などは 参考論文11)を参照していただければ幸いである。

\section{6. おわりに}

筆者らが最近確立することに成功した有機小分子 蛍光プローブの論理的な設計法により，開発可能な 蛍光プローブの種類は飛躍的に増大し，害際，本稿 で紹介してきたように，生きている生物試料の中で 起こる各種イベントを可視化する新規蛍光プローブ 群の開発に成功した。開発した蛍光プローブ群は, 細胞培養液に添加するだけで，容易に細胞膜を通過 して生きている細胞に負荷することが可能であり， すぐにでも生物学領域研究に適用可能な実用性を持 つている。 また，論理的設計法を駆使して in vivo 用のプローブを精緻に設計・開発することで，極め て高精細なin vivo がんイメージングも可能である ことを明確に示すことにも成功した，確立に成功し たがんイメージング技術は，遺伝子操作を一切用い ていないため，その安全性が高い点も大きな特長で あり，患者さんに手術前日に上述のプローブ類を少 量投与するだけで，手術中に術者が治療すべきがん
部位を明確に判断でき，的確な蛍光内視鏡下手術， あるいは開腹外科手術時が可能となる日も近いと大 いに期待している.

\section{謝辞 本稿で前半に紹介した蛍光プローブ類} は, 筆者が東京大学大学院薬学系研究科薬品代謝化 学教室在籍中に, 長野哲雄教授を始め, 多くの大学 院生とともに開発したものである。後半に紹介した がんの蛍光イメージング研究は，米国 NIH/NCI の 小林久隆主任研究員との共同研究であり，小林先生 のアイディアなくしては達成できなかった成果ばか りである。実際のがんイメージングプローブの設 計・開発は，主に浅沼大祐博士，神谷真子博士（両 博士とも現東大大学院医学系研究科助教）とともに 遂行してきた。この場をお借りして，以上の皆様に 深謝いたします。

\section{REFERENCES}

1) Minta A., Kao J. P., Tsien R. Y., J. Biol. Chem., 264, 8171-8178 (1989).

2) Miura T., Urano Y., Tanaka K., Nagano T., Ohkubo K., Fukuzumi S., J. Am. Chem. Soc., 125, 8666-8671 (2003).

3) Tanaka K., Miura T., Umezawa N., Urano Y., Kikuchi K., Higuchi T., Nagano T, J. Am. Chem. Soc., 123, 2530-2536 (2001).

4) Umezawa N., Tanaka K., Urano Y., Kikuchi K., Higuchi T., Nagano T., Angew. Chem. Int. Ed., 38, 2899-2901 (1999).

5) Setsukinai K., Urano Y., Kakinuma K., Majima H. J., Nagano T., J. Biol. Chem., 278, 3170-3175 (2003).

6) Ueno T., Urano Y., Kojima H., Nagano T., $J$. Am. Chem. Soc., 128, 10640-10641 (2006).

7) Kenmoku S., Urano Y., Kojima H., Nagano T., J. Am. Chem. Soc., 129, 7313-7318 (2007).

8) Urano Y., Kamiya M., Kanda K., Ueno T., Hirose K., Nagano T., J. Am. Chem. Soc., 127, 4888-4894 (2005).

9) Kamiya M., Kobayashi H., Hama Y., Koyama Y., Bernardo M., Nagano T., Choyke P. L., Urano Y., J. Am. Chem. Soc., 129, 3918-3929 (2007).

10) Kobayashi T., Urano Y., Kamiya M., Ueno T., Kojima H., Nagano T., J. Am. Chem. 
Soc., 129, 6696-6697 (2007).

11) Urano Y., Asanuma D., Hama Y., Koyama Y., Barrett T., Kamiya M., Nagano T., Wata- nabe T., Hasegawa A., Choyke P. L., Kobayashi H., Nat. Med., 15, 104-109 (2009) . 